\title{
Geneza i sposoby aktualizacji zwrotu grać na $x$ fortepianach w tekstach prasy emigracyjnej (do końca lat 80. XX wieku)
}

\section{Origin and ways of updating of the expression grać na $x$ fortepianach in émigré press publications (till late 1980-ties)}

\author{
Jolanta Ignatowicz-Skowrońska \\ Wydział Filologiczny, Uniwersytet Szczeciński \\ al. Piastów 40 B, 71-065 Szczecin, Polska \\ e-mail: skjj2@poczta.onet.pI
}

\begin{abstract}
Abstrakt
W artykule obiektem rozważań są związki frazeologiczne z komponentem fortepian, nierejestrowane w większości słowników językowych dawnej i współczesnej polszczyzny. Celem rozważań jest weryfikacja kilku kwestii: czasu pojawienia się związków w polszczyźnie, ich autorstwa oraz pierwotnego znaczenia.
\end{abstract}

Slowa kluczowe: frazeologizmy; pochodzenie; semantyka.

\begin{abstract}
In this article the subject of our considerations are phrasemes with the component fortepiano (piano) that are not registered in most dictionaries of the old and contemporary Polish language. The objective of the considerations is the verification of several issues: the time of appearance of the phrasemes in the Polish language, their authorship and their original meaning.
\end{abstract}

Keywords: phrasemes; origin; semantics.

Związku grać na dwóch fortepianach i podobnych mu konstrukcji nie notują ani słowniki ogólne języka polskiego, poczynając od zbiorów XIX-wiecznych, a kończąc na opracowaniach współczesnych, ani większość słowników frazeologicznych. Leksykograficzne poświadczenia jego użyć odnalazłam jedynie w czterech źródłach. Po pierwsze, najwcześniej, bo w roku 2004, wyrażenie gra na wielu fortepianach $\mathrm{w}$ znaczeniu 'utrzymywanie dobrych stosunków, zwykle dla własnych korzyści, z wieloma pod względem przekonań osobami, partiami, stronnictwami, państwami itp.' zostało odnotowane w monografii Nowe słownictwo 
polskie. Materiaty z prasy lat 1993-2000, gdzie opatrzono je pochodzącym z 2000 roku cytatem z „Życia”: „My, Polacy, mamy skłonność do popadania w skrajności. Teraz na przykład odżegnujemy się od Rosji, stawiamy wyłącznie na struktury zachodnie. Tymczasem mądra polityka polega na grze na wielu fortepianach" (Smółkowa red. 2004: 228). Po drugie, związek zarejestrowano w wydanych w roku 2005 Skrzydlatych słowach Henryka Markiewicza i Andrzeja Romanowskiego. Pojawił się tam w postaci hasłowej polityczna gra na dwóch fortepianach ze wskazaniem, iż pochodzi z tekstu Juliusza Mieroszewskiego, zamieszczonego w paryskiej „Kulturze” w roku 1956 (nr 6) (Markiewicz, Romanowski 2005: 286). Po trzecie, konstrukcje grać na kilku (dwóch, wielu itp.) fortepianach 'utrzymywać dobre, korzystne relacje z wieloma osobami, instytucjami, państwami' i gra na kilku (dwóch, wielu itp.) fortepianach 'sztuka utrzymywania dobrych, korzystnych relacji z wieloma osobami, instytucjami, państwami' zostały zapisane w Polnisch-deutsches Wörterbuch der Neologismen Eriki Worbs, Andrzeja Markowskiego i Andreasa Megera (2007: 87). Przetłumaczono je jako odpowiednio auf mehreren, (zwei, vielen usw.) Klavieren spielen i Spiel auf mehreren, (zwei, vielen usw.) Klavieren tudzież zilustrowano kilkoma cytatami zaczerpniętymi ze źródeł internetowych z roku 2002 (1 cytat) i 2006 (4 cytaty):

Pamiętać też warto, że dzisiaj PO gra na bardzo wielu fortepianach, dla jednych ma spokojnego Tuska, dla innych cholerycznego Rokitę, jednym podaruje Schetynę, innym zaś Komorowskiego i Gronkiewicz-Waltz (trybuna.com.pl 2006).

Od tego czasu do dnia dzisiejszego jest uważany za człowieka Watęsy. A Watęsa, jak wiadomo, gra na wielu fortepianach naraz i nie zawsze czysto (www.mail-archive.com 2006).

Grzegorz Kurczuk, decydując się na błyskawiczna lokalna koalicję z Samoobrona, wysyła jasny sygnat: wobec partii chtopskich Sojusz stosować będzie zasadę ,dziel i rządź”. Ta swoista gra na dwóch fortepianach stużyć ma przede wszystkim zdyscyplinowaniu chtopskiego - sejmowego koalicjanta (abcnet.com.pl 2006).

Ale przecież gra na wielu fortepianach to byt wynalazek lewicy, gdy na jednym grat Kwaśniewski, na drugim Miller, wspierani przez niezłq orkiestre z Borowskim, Oleksym, Janikiem i wieloma innymi (trybuna.com.pl 2006).

Negocjacje z Uniq Europejska to gra na piętnastu fortepianach równocześnie (www.wprost. pl 2002).

Po czwarte, wariantywny zwrot grać na dwóch fortepianach/na dwa fortepiany z kwalifikatorem publicystyczne zanotował Piotr Fliciński w wydanym w roku 2012 Wielkim stowniku frazeologicznym. Opatrzył go definicją, uwypuklającą dwa odcienie znaczeniowe związku, a mianowicie: 'działać w dwóch obszarach, $\mathrm{w}$ dwóch kierunkach jednocześnie, często przeciwstawnych, wykluczających się; być dwulicowym', i zilustrował cytatem, w którym aktualizowany jest tylko pierwszy wariant: „Premier Rosji od dłuższego czasu gra na dwóch fortepianach, 
prowadząc politykę wewnętrzną utwierdzającą Rosjan w przekonaniu o istnieniu wielkiej Rosji, natomiast na zewnątrz okazując chęć zbliżenia do zachodniego świata" (Fliciński 2012: 77). Przytoczone dane sugerują, że pierwowzór interesującego nas frazeologizmu pojawił się $\mathrm{w}$ polszczyźnie po raz pierwszy $\mathrm{w}$ roku 1956, genetycznie jest skrzydlatym wyrażeniem autorstwa Juliusza Mieroszewskiego, współcześnie używanym w różnych postaciach wariantywnych i derywacyjnych. Zwraca też uwagę różnorodność definiowania związku w przytoczonych źródłach, która może sugerować ewolucję jego semantyki: dwa z nich - monografia Teresy Smółkowej Nowe stownictwo polskie oraz słownik polsko-niemieckich neologizmów - operują bowiem podobnymi definicjami, nieco inną podaje słownik Piotra Flicińskiego. Celem artykułu będzie weryfikacja kilku kwestii: czasu pojawienia się związku w polszczyźnie, jego autorstwa oraz pierwotnego znaczenia. Rozważania prowadzić będę, analizując najstarsze znane mi przykłady użyć połączeń z fortepianem w polszczyźnie. Zagadnieniami aktualizacji tytułowego związku w tekstach współczesnego języka polskiego zajmę się w oddzielnym opracowaniu.

Kwerendy prowadzone za pomocą różnych narzędzi, m.in. internetowych, przekonują, że przenośne konstrukcje z komponentem „fortepian” pojawiły się w polszczyźnie przed rokiem 1956. Jeśli wierzyć słowom profesora Józefa Antoniego Szaniawskiego, politologa, historyka i publicysty, swoista metafora fortepianu funkcjonowała już w dwudziestoleciu międzywojennym w związku z osobą Ignacego Paderewskiego, który miał „wygrać” Polskę u Wilsona na fortepianie w Białym Domu:

W programie jego koncertów prawie zawsze byty utwory Chopina. Tak właśnie dla sprawy niepodlegtości Polski zjednat prezydenta Wilsona, który proklamując przystapienie USA do I wojny światowej, jako jeden z warunków Ameryki ogłosił utworzenie wolnej i niepodległej Polski z dostępem do morza. Byla to jedna z najbardziej doniostych decyzji politycznych w sprawie polskiej w catym XX wieku! Stał za nia Paderewski. Później, już w czasach II Rzeczypospolitej, po 1918 r. powszechnie znany kawat głosit, że Paderewski „wygral” Polske u Wilsona na fortepianie w Bialym Domu. Stówko ,wygrat" miało oczywiście podwójne znaczenie ${ }^{1}$.

Nie udało mi się jednak odnaleźć innych stosownych jej poświadczeń, a z uwagi na sposób jej konceptualizacji - raczej wątpliwe jest, by to ona stanowiła pierwowzór analizowanych tutaj konstrukcji.

Najwcześniejsze cytaty, do których udało mi się dotrzeć, zawierające przykłady użycia związków z fortepianem, pochodzą z prasy emigracyjnej, przy czym najstarszy kontekst pochodzi z roku 1941 z artykułu Aleksandra Hertza opublikowanego w londyńskim „Dzienniku Polskim”. Hertz wypowiada się w nim krytycznie o działaniach i aktywności publicystycznej Stanisława Cata Mackiewicza i Ignacego Matuszewskiego, którzy - przypomnijmy - podczas II wojny

${ }^{1}$ Cyt. za: http://hej-kto-polak.pl/wp/?p=20919 [dostęp: 29.03.2015]. 
światowej, przebywając na emigracji, formułowali negatywne opinie na temat kapitulanckiej względem Związku Sowieckiego polityki uprawianej przez generała Sikorskiego i jego współpracowników². Pisał Hertz:

(1) Nie nauczył się niczego $w$ tej wojnie pan Cat-Mackiewicz i nie nauczył się niczego tak inteligentny i madry człowiek, jak pan pulkownik Matuszewski. (...) Wymienilem jednym tchem panów Cata-Mackiewicza i Matuszewskiego. Albowiem ludzi tych, tak pod wieloma względami różnych, tączy bardzo dużo. Można by rzec, że na dwóch fortepianach grają tę samq melodie, pan Mackiewicz w Londynie, pan Matuszewski - w New Yorku. A melodia w rzeczywistości jest stara, przedwojenna ${ }^{3}$.

Użyte w powyższym cytacie rozbudowane sformułowanie na dwóch fortepianach graja tę sama melodię, pan Mackiewicz $w$ Londynie, pan Matuszew$\boldsymbol{s k i}-\boldsymbol{w}$ New Yorku jest więc ozdobnym, metaforycznym określeniem tego, że wspomniane osoby, przebywając $\mathrm{w}$ różnych miejscach, wyrażają identyczne opinie, które zresztą nie są niczym nowym. Podobną myśl oddano w innym artykule traktującym o tych samych postaciach, zamieszczonym w wydawanym w Stanach Zjednoczonych „Robotniku”. Tekst opublikowano w roku 1942 pod znamiennym tytułem Sobowtór londyński. Gra na dwóch fortepianach ${ }^{4}$.

Przytoczone fakty każą wątpić w to, że Juliusz Mieroszewski był autorem metafory o dwóch fortepianach, choć trzeba podkreślić, że wydatnie przyczynił się do jej popularyzacji5. Posługiwał się nią często na łamach paryskiej „Kultury”, przy czym cytat przywołany w Skrzydlatych słowach wcale nie był pierwszym, w którym się do niej odwołał i na dodatek został przez autorów leksykonu błędnie zlokalizowany. Nie pochodzi on bowiem z roku 1956 z rubryki Materiaty do refleksji, lecz z zamieszczonego w 1967 roku w „Kulturze” w dziale „Archiwum polityczne" artykułu Mieroszewskiego pod tytułem Atlantyk-Pacyfik. Publicysta posługuje się w nim wyrażeniem dwukrotnie: raz w postaci gra na „dwóch fortepianach”, drugi raz w formie polityczna gra ,na dwóch fortepianach”:

(2) W obecnej epoce Europa w równej mierze leży nad Atlantykiem jak i nad Pacyfikiem. Ów fakt móglby być wygrany z niezmierna korzyścia - gdyby Europa zachodnia była zjednoczona i zdolna do jednolitego działania politycznego. Można by wówczas podjąć grę „na dwóch fortepianach". W Azji Amerykanie powstrzymaliby Chiny-Europa zaś, kokietujac Pekin, mogłaby wywrzeć potężny nacisk na Rosję. W tej sprawie trudno wyobrazić sobie korzystniejsza koniunkture niż obecnie. Niestety Europa nie jest zjednoczona i tym samym nie jest zdolna do politycznej gry „na dwóch fortepianach” (,Kultura” 1967, nr 1).

${ }^{2}$ Szerzej na ten temat S. Cenckiewicz: http://www.videofact.com/polska/matuszewski.html [dostęp: 15.04.2015].

3 A. Hertz, Nowy czy stary świat pana pułk. Matuszewskiego, „Dziennik Polski”, 7 grudnia 1941; cyt. za: http://www.videofact.com/polska/matuszewski.html [dostęp: 31.12.2014].

${ }^{4}$ Ibidem.

${ }^{5}$ Jest to dość powszechne zjawisko w procesie uskrzydlania się pierwotnych cytatów. Szerzej na ten temat Chlebda 2005: 166-168. 
W cytacie tym wyrażenie $\boldsymbol{n a} \boldsymbol{d} \boldsymbol{d} \boldsymbol{w}$ ć $\boldsymbol{h}$ fortepianach wzięte jest w cudzysłów, co jest odautorskim sygnałem jego metaforyczności, a z całego kontekstu wynika, że owe dwa fortepiany to dwie różne metody, dwa różne narzędzia, które zastosowane łącznie mogłyby zagwarantować ład i bezpieczeństwo w polityce globalnej.

Jak wspominałam, przykłady tych aktualizacji są - jeśli chodzi o Mieroszewskiego - dość późne. Bliski współpracownik Jerzego Giedroycia i czołowy felietonista „Kultury” - jak wynika z dotychczasowych poszukiwań - po raz pierwszy metaforą fortepianu posłużył się w roku 1950 i przez kolejnych ponad dwadzieścia lat często do niej wracał, używając jej w różnych postaciach formalnych: gra na dwóch klawiszach, grać na dwóch fortepianach („Kultura” 1950, nr 9, s. 80; „Kultura” 1957, nr 9, s. 7; „Kultura” 1974, nr 11, s. 56), grać na dwa fortepiany („Kultura” 1953, nr 6, s. 115), grać wylqcznie na jednym fortepianie, „fortepian rosyjski” "nas nie interesowal, zasiadać do rosyjskiego fortepianu („Kultura” 1956, nr 6, s. 76), gra na dwóch fortepianach („Kultura” 1973, nr 6, s. 68; „Kultura” 1967, nr 1), polityczna gra na dwóch fortepianach („Kultura” 1967, nr 1), doktryna „gry na dwóch fortepianach” i polityka „gry na dwóch fortepianach” („Kultura” 1974, nr 11, s. 57). Konstrukcje te służyły Mieroszewskiemu do sygnalizowania treści związanych z rozmaitymi strategiami zagranicznej i polskiej polityki.

Sowiecką politykę zagraniczną charakteryzuje w artykule pochodzącym z roku 1950. Posłużył się w nim dwoma określeniami: gra na dwóch klawiszach i grać na dwóch fortepianach, zwracając w ten sposób uwagę na fakt, że Związek Sowiecki wykorzystuje różne, często wewnętrznie sprzeczne narzędzia dla realizacji własnych interesów:

(3) Tego rodzaju strategia przynosi Sowietom olbrzymie korzyści. Gra na tych dwóch klawiszach pozwala im przede wszystkim nie dopuścić do petnej mobilizacji opinii w krajach Zachodu $i$ w Stanach Zjednoczonych. Tylko zagrożenie na szczeblu „B” t j. groźba bezpośredniego światowego konfliktu zmobilizowałaby w pełni 150 milionów Amerykanów i 70 milionów obywateli brytyjskiego Commonwealth. Tylko wówczas wyjętoby spod prawa komunistów. W Anglii powstałby rzad koalicyjny i wszystko podporzadkowano by jednemu celowi - tj. zwycięstwu. Akcja prowadzona na szczeblu „, A” tj. ,zimnej wojny” nie mobilizuje w petni opinii, nie przykuwa kapryśnej uwagi prasy krajów demokratycznych, pozwala wierzyć, że przecież mamy pokój. Polityka sowiecka grając na tych dwóch fortepianach bacznie obserwuje reakcje na Zachodzie. Gdy fala antykomunistycznych nastrojów wzrasta pojawia się natychmiast monachijski gołąek pokoju. Stalin proponuje zawsze Monachium „,na raty” tatwiejsze do przełknięcia (,Kultura” 1950, nr 9, s. 80).

Większość użyć związków z fortepianem u Mieroszewskiego dotyczy jednak polskiej polityki niepodległościowej, zarówno historycznej, z okresu poprzedzającego I i II wojnę światową, z czasów II wojny, jak i współczesnych mu lat powojennych. W roku 1956 na przykład, analizując przyczyny klęski wrześniowej i, później, utraty suwerenności przez nasz kraj, zwraca uwagę na fakt, że ówczesna polska polityka zagraniczna była jednostronna, posługiwała 
się tylko jednym narzędziem, stawiając na sojusze i porozumienia z krajami Zachodu. Rozwijając tę kwestię, posługuje się rozbudowaną metaforę fortepianu:

(4) Od początku graliśmy wylqcznie na jednym fortepianie. Graliśmy uporczywie na nim nawet wówczas, kiedy bylo calkowicie pewne, że gramy sobie a niebu. „Fortepian rosyjski” nas nie interesowat. Nie wydaliśmy dwóch niezależnych koncepcji (Dmowski-Pitsudski) wykazując zdumiewająca zgodność w pro-zachodnim nastawieniu w chwili, kiedy Polska zmieniała swój geopolityczny mianownik i stawała się z najbardziej na Wschód wysuniętego bastionu Zachodu najbardziej na Zachód wysuniętym bastionem... Wschodu. Mikołajczyk rozmawiat ze Stalinem ale to nie byt już moment by zasiadać do rosyjskiego fortepianu. $\mathrm{Na}$ rozmowy z Rosją było wówczas o trzy lata za późno („Kultura” 1956, nr 6, s. 76).

Ważna w tym cytacie jest również wzmianka o dwóch strategicznych postaciach polskiej historii i ruchu niepodległościowego: Józefie Piłsudskim i Romanie Dmowskim, którzy w przeciwieństwie do swoich następców stworzyli dwie niezależne, wzajemnie uzupełniające się koncepcje, w opinii felietonisty sprzyjające odzyskaniu wolności przez Polskę w 1918 roku. Dodajmy też, że taktyka samego Piłsudskiego, polegająca na wykorzystywaniu w walce niepodległościowej „struktur zarówno legalnych, jak nielegalnych”, w dyskursie historyków określana jest mianem gry na dwóch fortepianach.

Do trudnych spraw polskiej polityki wschodniej Mieroszewski wrócił w roku 1973 w artykule zatytułowanym Polska ,Ostpolitik”, przywołując wyrażenie gra na dwóch fortepianach:

(5) Odnositem się zawsze z wielkq nieufnościq do postaw jednolitych (zwarci, silni i gotowi). Jednak Rosja w polskiej perspektywie politycznej stanowi taki super-problem, że jako naród nie możemy pozwolić sobie na 5 czy 6 różnych programów wschodnich. Mądra zasada „gry na dwóch fortepianach" - winna w tym szczególnym wypadku dotyczyć taktyki lecz nie podstawowych zasad („Kultura” 1973, nr 6, s. 68).

Wiele aktualizacji związków z fortepianem służy też Mieroszewskiemu do charakteryzowania odmiennych zadań, które stoją przed politykami działającymi w kraju i na emigracji. Charakterystyczny w tej materii jest już cytat z roku 1957, pochodzący z tekstu pod znamiennym tytułem „Dwa fortepiany”. W jego treści pojawia się zwrot grać na dwóch fortepianach, podkreślający zalety koordynacji polityki polskiej uprawianej w kraju i za granicą:

${ }^{6}$ Określeniem posługuje się na przykład B. Urbankowski, por.: „Gra na dwóch fortepianach / Tym określeniem przyjęło się nazywać wykorzystywanie struktur zarówno legalnych, jak nielegalnych. Tak działał Piłsudski w Galicji. W czerwcu 1908 z inspiracji przyszłego Naczelnika powstał tajny Związek Walki Czynnej, pierwsze koła budowano na bazie „szóstek milicyjnych” PPS kierowanych przez Sosnkowskiego", por.: http://www.jpilsudski.org/artykuly-publicystykafelietony/felietony/item/2307-niepodleglosc-jako-wyzwanie-o-marzeniach-i-pracach-jozefapilsudskiego [dostęp: 18.04.2015]. 
(6) Młody inżynier z Polski był dość zaskoczony gdy na jego prośbę by przytoczyć jakiś konkretny przykład politycznych możliwości emigracji wymienitem pożyczkę amerykańską. W tej sprawie emigracja i Polonia odegrała wybitna rolę. Niestety nie leżato $w$ zakresie możliwości Polaków zagranicznych wydatniejsze zwiększenie sumy - niewątpliwe jednak leżato $w$ granicach możliwości politycznych emigracji storpedowanie catego projektu. Wbrew opinii emigracji politycznej i Polonii Amerykanie nie byliby udzielili pożyczki. Niewatpliwie idealnym rozwiązaniem byłoby gdyby polityka Polska grać mogla na dwóch fortepianachkrajowym i emigracyjnym („,Kultura” 1957, nr 9, s. 7).

Jeszcze dobitniej uwypuklają tę kwestię dwa cytaty pochodzące z roku 19747 . Pojawiają się w nich użycia aż trzech związków: grać na dwóch fortepianach, doktryna ,gry na dwóch fortepianach” i polityka „gry na dwóch fortepianach”:

(7) Narody w niewoli graja zawsze na dwóch fortepianach - maja zarówno ugodowców jak i niepodleglościowców. Ugodowcy spetniaja swoje zadanie w perspektywie, jeżeli wspótpracy z zaborca nie traktuja za drabinę do osobistej kariery lecz staraja się uratować to, co jest do uratowania i rozbudować to, co jest do rozbudowania („Kultura” 1974, $\mathrm{nr}$ 11, s. 56)

(8) Z doktryny „gry na dwóch fortepianach” wynika jasno, że emigracja winna głosić i reprezentować postulaty, których w kraju ani reprezentować ani głosić nie wolno. Polityka „gry na dwóch fortepianach" nie ma nic wspólnego z siedzeniem na dwóch krzesłach. Niepodległościowcy na emigracji nie moga mieć nic wspólnego z reżymowa polityka ugody - winni natomiast mówić głośno i dobitnie w imieniu dziesiątków milionów Polaków w Kraju, którzy pragna przywrócenia w Polsce petnego prawa do samostanowienia („Kultura” 1974, nr 11, s. 57).

Używanie zmetaforyzowanych konstrukcji z komponentem fortepian było charakterystyczne nie tylko dla samego Mieroszewskiego jako czołowego felietonisty paryskiej „Kultury”, ale dla wielu ludzi z nią związanych. Metafora fortepianu pojawiała się w korespondencji prywatnej między Jerzym Giedroyciem a Juliuszem Mieroszewskim czy Jerzym Giedroyciem a Janem Nowakiem-Jeziorańskim. W liście tego ostatniego do Giedroycia, datowanym na 8 stycznia 1971, roku czytamy:

(9) Uważam, że nie ma najmniejszego sensu, byśmy stosunki między nami ustawiali na płaszczyźnie jakiejś rywalizacji czy zawodowych zazdrości, już choćby dlatego, ze instrumenty, którymi dysponujemy, sa zupetnie odmienne i że w polityce dobrze jest zawsze grać na kilku fortepianach, choćby nawet nie byty one wspótbrzmiace (cyt. za: http://niniwa22.cba.pl/ jan_nowak_emisariusz.htm data dostępu: 13.04.2015).

Warto też wspomnieć, że metafora ta była na tyle charakterystyczna dla sposobu myślenia politycznego naczelnego redaktora „Kultury” i całego pisma, że została wykorzystana w książce Janusza Korka poświęconej paryskiej „Kulturze” jako tytuł jednego z podrozdziałów opisującego linię polityczną pisma w latach 1955-1964: Gra na dwóch fortepianach (lata 1955-1964) (Korek 2008). Z kolei Magdalena Grochowska (2009), autorka biografii Jerzego Giedroycia, umieści-

7 Juliusz Mieroszewski zmarł w Londynie 21 czerwca 1976 r. 
ła hasło fortepiany w alternatywnym alfabecie Giedroycia, pisząc: Fortepiany - dwa: ten, który podgrzewa ewolucję, i ten, który roznieca bunt. Należy grać na obydwu jednocześnie ${ }^{8}$.

Połączenia z fortepianem pojawiały się też na łamach innej niż paryska „Kultura" prasy emigracyjnej aż do lat 80 . XX wieku. W roku 1964, wystąpiły dwukrotnie na łamach dodatku do londyńskich „Wiadomości”, pisma „Na Antenie”, we wzmiance poświęconej metodom działań prezesa Związku Literatów Polskich Jarosława Iwaszkiewicza, który do czasu ,listu 34" grat na dwa fortepiany. Na forum międzynarodowym występowat $w$ roli liberata, $w$ Polsce nazywano go prezesem naganiaczy:

(10) Prezes Zwiazku Literatów Iwaszkiewicz do czasu ,, listu 34” gral na dwa fortepiany. Na forum międzynarodowym wystepowat $w$ roli liberała, w Polsce nazywano go prezesem Naganiaczy. (...). Zarzad P.E.N. Clubu projekt odpowiedzi odrzucit, wobec czego Iwaszkiewicz z P.E.N. Clubu wystapit. W ten sposób skończyla się jego rola na arenie międzynarodowej, a przypuszczać należy, że skończyła się także jego gra na krajowym fortepianie: wydaje się watpliwe, aby nawet mocodawcom Iwaszkiewicza udało się wymusić na jesiennym zjeździe literatów w Lublinie ponowny wybór Iwaszkiewicza na prezesa Zwiąku (,Na Antenie” 1964, nr 7, s. 8).

W roku 1965 w „Wiadomościach” posłużył się nią Wacław Alfred Zbyszewski, dziennikarz i publicysta związany m.in. z „Głosem Ameryki”, „Dziennikiem Polskim”, „Dziennikiem Żołnierza”, „Kulturą” i Rozgłośnią Polską Radia Wolna Europa: (11) „Druga stała zasada polityki gaullistowskiej, to „les mains libres”, wolne ręce. Stale próbuje grać na dwóch fortepianach”. („Wiadomości” 1965, nr 42, s. 2).

W roku 1988 w piśmie „Na Antenie” w okolicznościowym tekście z okazji 11 listopada przywołał ją czterokrotnie Marek Łatyński, dziennikarz, dyplomata, szef Rozgłośni Polskiej Radia Wolna Europa w Monachium w latach 1987-1989:

(11) Przez te lata Polska poszła naprzód. Skrawek po skrawku odzyskiwała swoja suwerenność. Przyczynity się do tego wysiłku wielu ludzi, którzy na różnych grali fortepianach. Te wysitki trwają. (...) żeby różni ludzie, skoro nie moga wszyscy być przygotowani naraz na wszystkie ewentualności dzielili się rolami-by, innymi słowy, działali zgodnie ze znana wszystkim, ale pogardzana przez wielu teoria kilku fortepianów. (...) Ale także działania podejmowane już w czasie Wielkiej Wojny - i działania zbrojne Pitsudskiego i działania dyplomatyczne Romana Dmowskiego, które wprowadzity Polskę w szeregi zwycięskiej koalicji. Owa gra więc na dwóch co najmniej fortepianach. (...) Była to gra na dwóch fortepianach. Zwolennicy każdej z orientacji zgodnie z każdq działali („Na Antenie” 1988, nr 375, s. 1).

${ }^{8} \mathrm{http}: / /$ wyborcza.pl/1,75475,8371137,Magdalena_Grochowska_i_alternatywny_alfabet_ Giedroycia.html\#ixzz3MYHHIPCZ [dostęp: 21.12.2014]. 
Podsumowując powyższe rozważania, należy podkreślić, że związki z komponentem fortepian były obecne w polszczyźnie od co najmniej lat 40. XX wieku, funkcjonowały w prasie emigracyjnej, zwłaszcza w środowisku osób związanych z paryską „Kulturą", które to środowisko wydatnie przyczyniło się do ich popularyzacji. Jednostki tego typu ukształtowały się zatem w kręgu inteligencji i miały ściśle ograniczony zasięg użycia: pojawiały się w języku pisanym, w tekstach tworzonych przez elity ówczesnego społeczeństwa i adresowanych również do elit. Sam koncept gry na x fortepianach bazuje na skojarzeniach z 'maestrią', 'wirtuozerią,, 'perfekcjonizmem', 'harmonią', 'synchronizacją działan', i sensy te były w sposób mniej lub bardziej wyraźny sygnalizowane w przytaczanych cytatach, które w zdecydowanej większości dotyczyły wielkiej polityki i dyplomacji: polityki państw zachodnich, polityki Rosji w okresie II wojny światowej, a później w czasie zimnej wojny, polskiej polityki zagranicznej uprawianej przed I i II wojną światową, zwłaszcza polskiej polityki niepodległościowej. Użyte w takich realiach różnorodne konstrukcje $\mathrm{z}$ fortepianem, często operowały znakiem cudzysłowu, co przekonuje, że znajdowały się one wówczas na etapie frazeologizacji (Lewicki 2003: 165-166) i służyły do wyrażania treści „w sposób umiejętny wykorzystywać różne, często przeciwstawne metody, narzędzia, instrumenty do realizacji określonych celów". Z uwagi na wyraźnie zaznaczający się w treści metaforycznej analizowanych związków sem przeciwstawności metod wykorzystywanych do osiągnięcia jakiegoś celu konstrukcje tego typu - jak wiele im podobnych (por. Osiołkowi $w$ żłoby dano, $w$ jednym owies, $w$ drugim siano czy plusy dodatnie i plusy ujemne) - odzwierciedlają typowo ludzką skłonność do dychotomicznego ujmowania świata.

\section{Bibliografia}

(www 1) http://hej-kto-polak.pl/wp/?p=20919 [dostęp: 29.03.2015].

(www 2) http://www.jpilsudski.org/artykuly-publicystyka-felietony/felietony/item/2307-niepodleglosc-jako-wyzwanie-o-marzeniach-i-pracach-jozefa-pilsudskiego [dostęp: 18.04.2015].

(www 3)

http://wyborcza.pl/1,75475,8371137,Magdalena_Grochowska_i_alternatywny_alfabet_Giedroycia. html [dostęp: 21.11.2014].

(www 4) http://www.videofact.com/polska/matuszewski.html [dostęp: 15.04.2015].

(www 5) http://www.videofact.com/polska/matuszewski.html [dostęp: 31.12.2014].

Chlebda W., 2005, Szkice o skrzydlatych stowach. Interpretacje lingwistyczne, Opole.

Fliciński P., 2012, Wielki słownik frazeologiczny, Poznań.

Grochowska M., 2009, Jerzy Giedroyc. Do Polski ze snu, Warszawa.

Korek J., 2008, Paradoksy paryskiej kultury. Styl i tradycje myślenia politycznego, Katowice.

Lewicki A.M., 2003, Zakres frazeologii, w: Lewicki A. M., Studia z teorii frazeologii, Łask.

Markiewicz H., Romanowski A., 2005, Skrzydlate słowa. Wielki słownik cytatów polskich i obcych, Kraków.

Smółkowa T. (red.), 2004, Nowe słownictwo polskie. Materiaty z prasy lat 1993-2000. Część 1: $A-H$, Kraków.

Worbs E., Markowski A., Meger A., 2007, Polnisch-deutsches Wörterbuch der Neologismen, Wiesbaden. 